\title{
Correlation of Melanin Content with Collagen Density in Keloid Patients
}

\author{
Herman Y. L. Wihastyoko ${ }^{1,2 *}$, David S. Perdanakusuma ${ }^{3}$, Setyawati Soeharto ${ }^{4}$, Edi Widjajanto ${ }^{5}$, Kusworini Handono ${ }^{5}$, \\ Bambang Pardjianto ${ }^{2,6}$ \\ ${ }^{1}$ Doctoral Program, Faculty of Medicine, Brawijaya University, Malang 65145, Indonesia; ${ }^{2}$ Plastic, Aesthetic and Reconstruction \\ Surgery Consultant, Saiful Anwar General Hospital, Malang 65111, Indonesia; ${ }^{3}$ Department of Plastic Reconstructive and \\ Aesthetic Surgery, Dr. Soetomo General Academic Hospital, Faculty of Medicine, Universitas Airlangga, Surabaya 60286, \\ Indonesia; ${ }^{4}$ Department of Pharmacology, Faculty of Medicine, Brawijaya University, Malang 65145, Indonesia; ${ }^{5}$ Department \\ of Clinical Pathology, Faculty of Medicine, Brawijaya University, Malang 65145, Indonesia; ${ }^{6}$ Faculty of Medicine and Health \\ Sciences, State Islamic University of Malang, Malang 65144, Indonesia
}

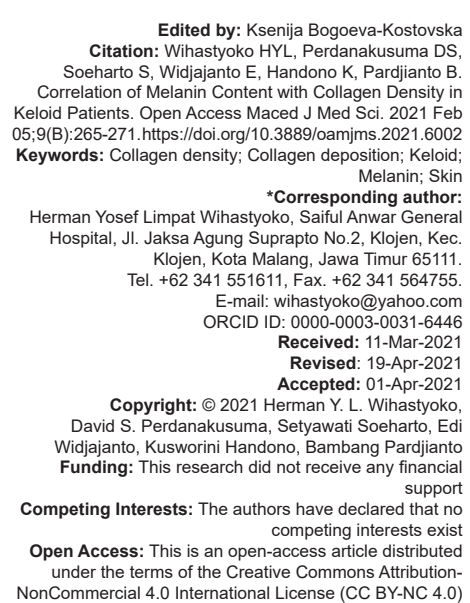

Edited by: Ksenija Bogoeva-Kostovska Citation: Wihastyoko HYL, Perdanakusuma DS Citation: Wihastyoko HYL, Perdanakusuma DS,
Soeharto S, Widjajanto E, Handono K, Pardjianto B Correlation of Melanin Content with Collagen Density in Keloid Patients. Open Access Maced J Med Sci. 2021 Feb 05;9(B):265-271.https://doi.org/10.3889/oamjms.2021.600 Melanin; Skin *Corresponding author: Herman Yosef Limpat Wihastyoko, Saiful Anwar General Hospital, Jl. Jaksa Agung Suprapto No.2, Klojen, Kec. Klojen, Kota Malang, Jawa Timur 65111 Tel. +62 341 551611, Fax. +62 341564755 E-mail: wihastyoko@yahoo.com
ORCID ID: 0000-0003-0031-6446 Received: 11-Mar-2021 Received: 11-Mar-2021 Accepted: 01-Apr-2021 Copyright: @ 2021 Herman Y. L. Wihastyoko, David S. Perdanakusuma, Setyawati Soeharto, Ed Widjajanto, Kusworini Handono, Bambang Pardjianto Funding: This research did not receive any financial Competing Interests: The authors have declared that no competing interests exis Open Access: This is an open-access article distributed under the cerms of the Creal 4 Conme (CC BY-NC 4.0)

\begin{abstract}
BACKGROUND: Keloid is a form of wound healing that results from fibrous tissue activity. It can develop beyond the boundaries of the original wound, extends into the dermis layer, and disrupting the appearance. Previously, no studies have revealed a correlation between melanin pigment and keloid.

AIM: This research aimed to describe the correlation between melanin concentration and collagen deposition in keloid tissue.

MATERIALS AND METHODS: A prospective study conducted through the application of a cross-sectional analytic survey method. The color of the skin was measured using a chromameter, and a histopathologic examination was performed on the skin surrounding the keloid, as well as the keloid tissue. Data were analyzed using a t-test, correlation, and linear regression statistics.

RESULTS: The results showed a significant difference between melanin concentration and collagen deposition in the skin surrounding the keloid tissue. No significant difference was observed between melanin concentration in the surrounding skin of keloid and those in the keloid tissue, as well as collagen deposition. Meanwhile, the melanin concentration in the surrounding skin of keloid and keloid tissue had a significant relationship with fibrocytes number. CONCLUSION: There is a significant correlation between melanin concentrations and collagen density in the keloid tissue.
\end{abstract}

\section{Introduction}

Keloid is a form of wound healing that results from fibrous tissue activity. It can develop beyond the boundaries of the original wound and extends into the dermis layer. It is characterized by a wide, slightly soft, and shiny surface lump and disrupting the appearance. The exact mechanism for its occurrence has not been fully resolved, although several theories have explained its causes [1], [2], [3].

From January to December 2016, the Polyclinic of Plastic Surgery Clinic and Integrated Central Surgical Building of Dr. Soetomo Hospital received 459 (9.8\%) patients with new and old hypertrophic keloids. From these data, 96 (20.9\%) were there because of the keloid. In general, their age was 10-45 years, with an average of 25 years. Although the cause of keloid is still unknown, ethnic differences have been recognized to be one of the factors that influence its development [4]. Individuals with dark-skinned ethnic backgrounds such as the Negroid and Mongoloid races, including Blacks, Hispanic, and Asian individuals, can develop it faster compared with white-skinned people such as Caucasians. The ratio of keloids between dark- and light-skinned people is between 5 and 18.7. Meanwhile, no case has been reported in albinos [3], [5], [6].

Melanin is a natural pigment in human and animal skin. It has different types of colors, and it is an indicator determining human skin color [2], [7]. The measurements of melanin or skin color concentration can be done using a spectrophotometer or colorimeter, also known as a chromameter, and the type to be used must be in accordance with the Commission International d'Eclairage (CIE) laboratory standards. The color system used by CIE is based on the position of $a^{*} b^{*}$ and $L^{*} C^{*}{ }_{a b}$ [8], [9], [10]. Melanin can also be observed using the hematoxylin-eosin (HE) staining technique [11]. 
The accumulation of unbalanced collagen in keloids occurs because of interference in its synthesis and degradation. Collagen is a triple helix protein located in the extracellular matrix. It acts as tissue repair, and its highest amount could be found in collagen type I $(80 \%)$ [12]. However, it is important to know its content in the body by measuring collagen density [13], which affects keloid formation.

No studies have revealed a correlation between melanin pigment and keloid. Goyal's theory proposed that melanocytes interact with fibroblasts in the dermal layer and cause proliferation, secretion, and collagen deposition of fibroblasts [14]. Other studies also stated that high melanin content can disrupt the degradation of collagen [15]. Therefore, this study aims to determine the relationship between melanin and collagen density in keloid patients.

\section{Materials and Methods}

\section{Sample preparation}

This research was a prospective study using a cross-sectional analytical survey as well as a histopathological approach. It was conducted at the Polyclinic of Plastic Surgery and Integrated Central Surgical Building of the Dr. Soetomo hospital in Surabaya from January to June 2016. The total of the patients with keloid was obtained using the formula of Pudjirahardjo et al. [16] was shown in Equation 1.

$$
n=\frac{N z^{2} p(1-p)}{N d^{2}+z^{2} p(1-p)}
$$

Where $\mathrm{n}$ is the size of the sample, $\mathrm{n}$ is the size of the population, and $z$ is the normal standard value of magnitude, which depends on $\alpha$; if $\alpha=0.05$, then $z=1.96$. $p$ is the probability of an event. The total number of keloid patients in Asia is $17.5 \%$; so, $p=$ 0.175 ; while $d$ is the amount of the tolerated deviation value (0.1). The total samples derived from the formula above are 35 patients. The initial research procedure included recording patients' demographics (age, sex, address, occupation, the location of keloid, etiology, previous history of keloid therapy, and duration of keloids).

\section{Measurement of the skin color}

The skin color around the keloid and the predilection area was measured (chest, deltoid, back, legs, and abdomen) using a chromameter to obtain the $L^{*}$ value as the expression of melanin content. The inner upper arm was examined as a control.

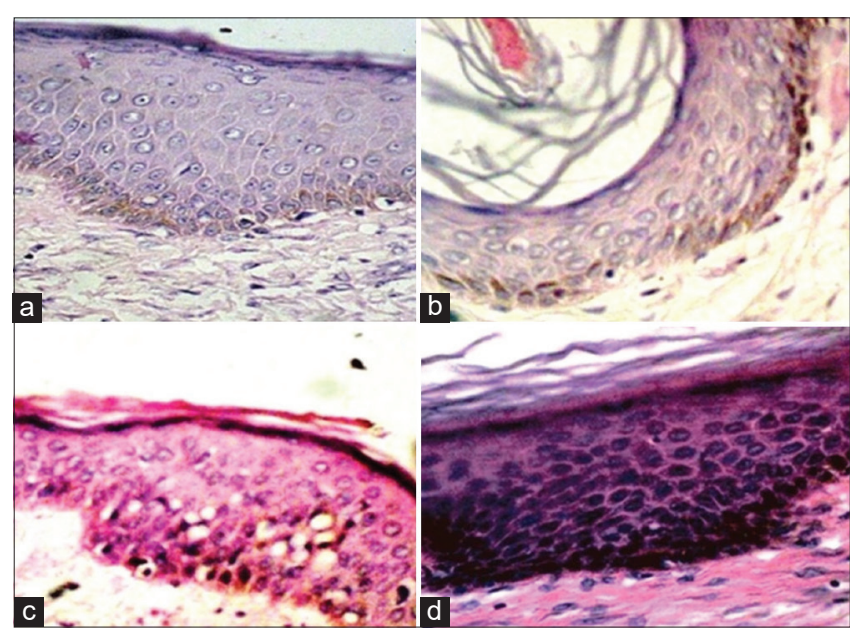

Figure 1: Histology scoring of melanin pigment (hematoxylin-eosin staining; magnification 400x). (a) light brown: 0-10 (average 5); (b) brown: 11-21 (average 16); (c) dark brown: 22-32 (average 27); (d) blackish-brown: 33-43 (average 38)

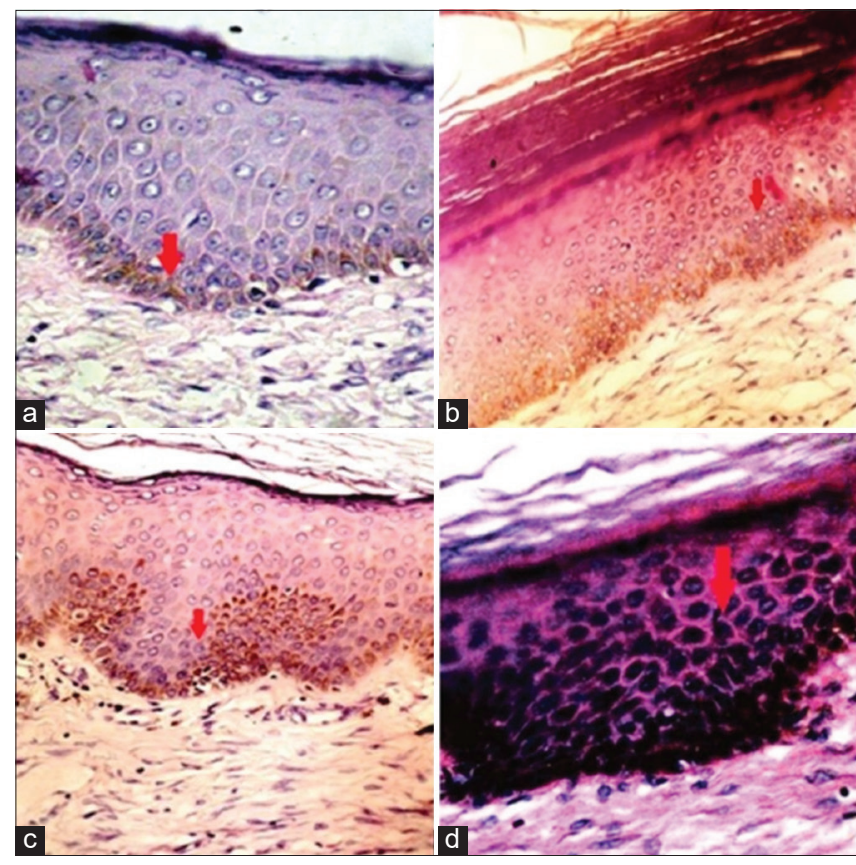

Figure 2: Distribution of keratinocyte cells containing melanin pigments in the epidermal layer (arrows); hematoxylin-eosin staining, magnification 400×. (a) Basal layer: 0-6 (average 3); (b) spinosum layer: 7-13 (average 10); (c) granulosum layer: 14-20 (average 17); (d) fourth layer of epidermis: 21-27 (average 24)

\section{Assessment of melanin content}

An excision of $0.25-0.5 \mathrm{~cm}$ was performed on the keloid tissue and the surrounding skin, and then the samples were fixated with $10 \%$ formalin. This sample is used to make the histology preparation and observe the content of melanin with a scoring system through a combined score based on (1) the gradation of melanin pigments ranging from light brown, brown, dark brown, to blackish-brown (Figures 1 and 2) distribution of keratinocyte cells containing melanin pigments in each layer of the epidermis (Figure 2). Each score was defined by an interval value, which was taken as the average, and the melanin pigment with a higher value as a 
dominant benchmark score. The sequence combination was obtained by summing the two average scores; thus, the combination score is obtained as follows:

The color score of the melanin pigment (Figure 1).

a. Interval 0-10 (average 5), for light brown melanin

b. Interval 11-21 (average 16), for brown melanin

c. Interval 22-32 (average 27), for dark brown melanin

d. Interval 33-43 (average 38), for blackish-brown melanin.

Distribution score of keratinocyte cells containing melanin pigments in the epidermal layer (Figure 2).

a. 0-6 (average 3), for keratinocyte cells containing melanin pigment in the basal layer

b. 7-13 (average 10), for keratinocyte cells containing melanin pigment in the spinosum layer

c. 14-20 (average 17), for keratinocyte cells containing melanin pigment in the granulosum layer

d. 21-27 (average 24), for keratinocyte cells containing pigment melanin in the fourth layer of epidermis.

The melanin content determination in the samples started by identifying the line between the normal skin region and the keloid region, and using a binocular microscope and closed-circuit television (CCTV) camera, it was observed that the melanin pigment in the epidermis layer started from the normal skin side. The method above produced 16 combination scores sequentially according to the sum of the results of each score. Each combination score was assessed at interval 10. The melanin content was determined based on the average of the combined score (Table 1).

Table 1: Combination score of melanin pigment

\begin{tabular}{lll}
\hline $\begin{array}{l}\text { Score combination } \\
\text { (Average number) }\end{array}$ & Melanin content & \\
\cline { 2 - 3 } A-1 (8) & Interval & Average \\
A-2 (15) & $0-10$ & 5 \\
B-1 (19) & $11-21$ & 16 \\
A-3 (22) & $22-32$ & 27 \\
B-2 (26) & $33-43$ & 38 \\
A-4 (29) & $44-54$ & 49 \\
C-1 (30) & $55-65$ & 60 \\
B-3 (33) & $66-76$ & 71 \\
C-2 (37) & $77-87$ & 82 \\
B-4 (40) & $88-98$ & 93 \\
D-1 (41) & $99-109$ & 104 \\
C-3 (44) & $110-120$ & 115 \\
D-2 (48) & $121-131$ & 126 \\
C-4 (51) & $132-142$ & 137 \\
D-3 (55) & $143-153$ & 148 \\
D-4 (62) & $154-164$ & 159 \\
\hline
\end{tabular}

\section{Measurement of collagen density}

Collagen density was measured based on the number of fibrocytes in the dermis layer of the skin. The fibrocytes were calculated using a binocular microscope equipped with CCTV cameras with a $1 \mathrm{~cm}^{2}$ counting room, which contains $0.5 \mathrm{~mm}^{2} 400$ small square planes. All tissues underwent the HE-staining procedure with 400× magnification.

\section{Ethical standards and informed consent}

All procedures followed the ethical standards of the committee on human experimentation (institutional and national) and with the Helsinki Declaration of 1975, as revised in 2000. Informed consent was obtained from all patients for being included in the study.

\section{Statistical analysis}

All data were analyzed using Microsoft Excel and SPSS Software. Normal distribution was assessed using Kolmogorov-Smirnov analysis. Independent tests were carried out on variable $L^{*}$ objective skin color values, melanin content scores, melanin density, and collagen density in the surrounding skin and keloid tissue based on the results of the histopathological examination. The t-test was used for independent samples, while a correlation test was used to determine the relationship between melanin scores and the number of fibrocytes. The effect of independent variables was analyzed by a regression test to know if there is a significant relationship between them.

\section{Results}

The results showed that most of the keloid samples were obtained from females (17) than males (9) from a total of 26 patients. Based on sex, it was found that burns are the most common cause of keloids in men $(30.8 \%)$, whereas piercing was a more common cause for women (30.8\%) (Figure 3a). Based on the

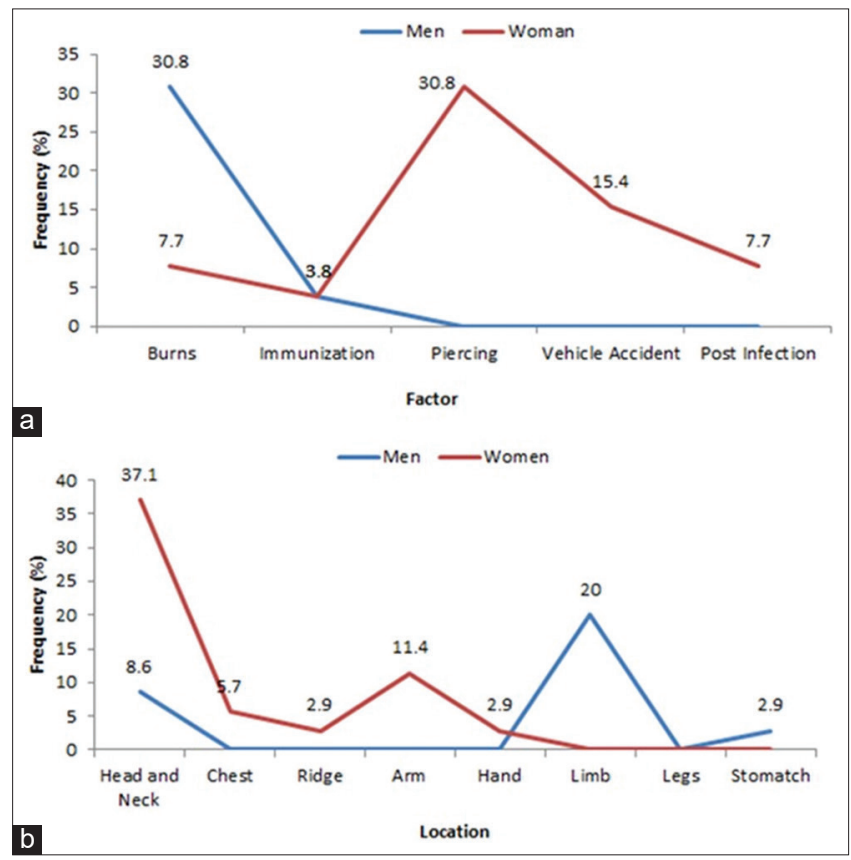

Figure 3: Distribution of keloid based on: (a) The causes and (b) Its location between men and women patients 


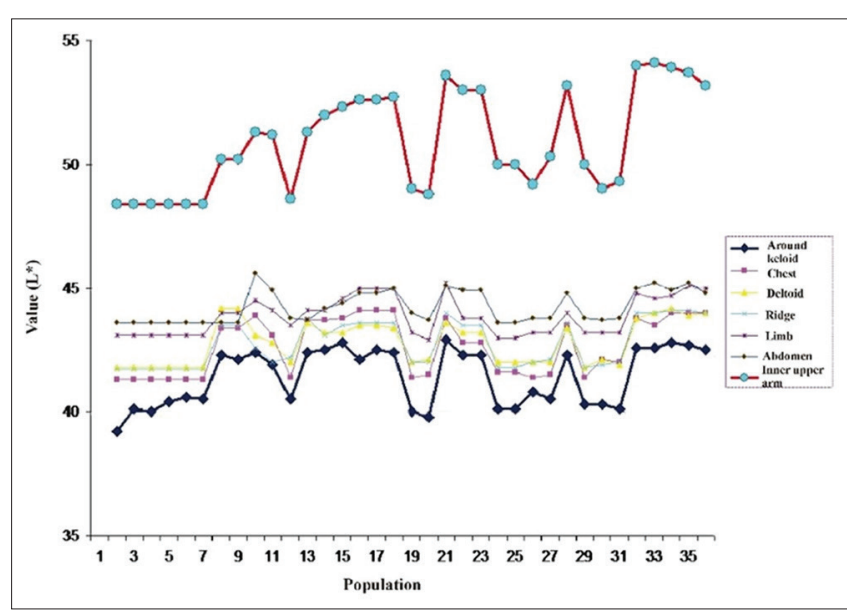

Figure 4: The result of $L$ * value

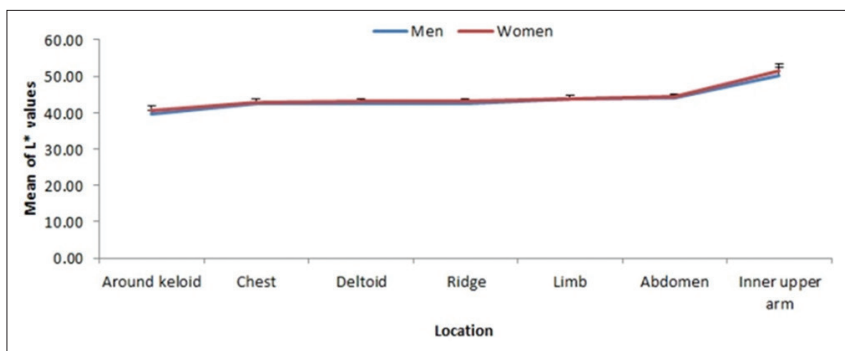

Figure 5: The result of melanin content and number of fibrocytes number based on the keloid region

location, most of the keloid excision tissues were found in the head and neck, especially in women (Figure 3b), whereas it was found in the leg in most of the men.

The $L^{*}$ result showed lower values in the area around the keloid (Figure 4). It was also discovered that its average value in women in each location was higher than in men (Figure 5). Meanwhile, its value around keloid in the ultraviolet (UV) light exposure was lower (39.95) than those located in areas not exposed (40.48). The results of the analysis of different tests showed that there is a significant difference between the $L^{*}$ value and the melanin content from histopathological observations, as well as between the content of melanin and collagen density in the surrounding skin and keloid tissue (Table 2).

Table 2: The different test of $L^{*}$ value with melanin content, melanin content, collagen density around keloid, and on keloid region

\begin{tabular}{lllll}
\hline Variable & t-test & & & \\
\cline { 2 - 5 } & $\mathrm{t}$ & $\mathrm{df}$ & Mean-diff & Sig. \\
\hline $\mathrm{L}^{*}$ value-melanin content around keloid region & -5.206 & 68 & -25.88 & 0.000 \\
Melanin content around keloid-keloid region & -10.66 & 68 & -69.14 & 0.000 \\
Collagen density around keloid-keloid region & 21.46 & 68 & 334.85 & 0.000 \\
\hline
\end{tabular}

In general, the surrounding skin had higher melanin content, but the number of fibrocytes in the same location was lower. However, this is in contrast with the results obtained for fibrocytes, which showed that women had a higher number than men in all locations (Table 3 ). Based on UV light exposure, more keloids (74\%) were observed in areas mostly exposed to UV light compared with areas that are less exposed (26\%). The melanin content in keloid exposed to UV light had a higher average

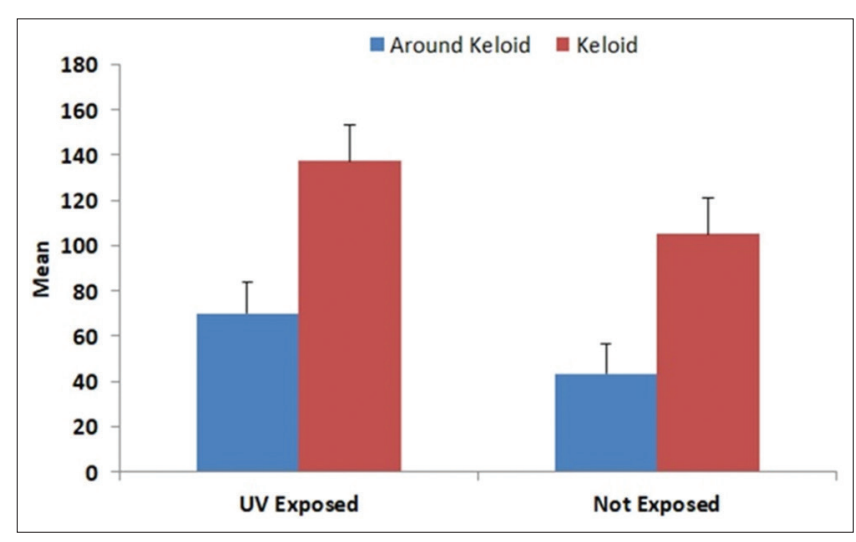

Figure 6: The melanin content based on the ultraviolet light exposure

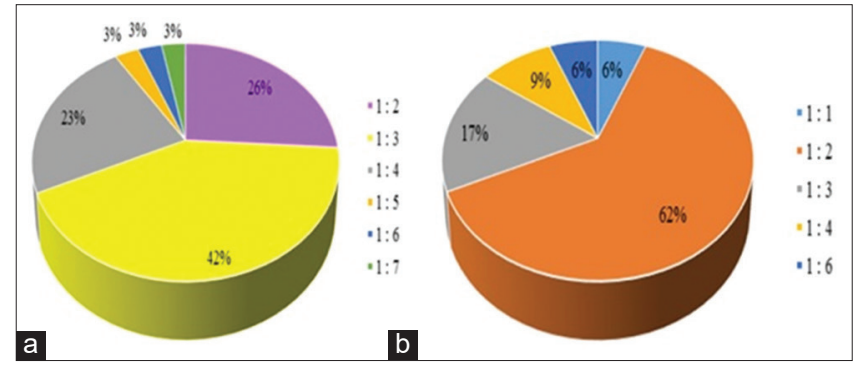

Figure 7: The ratio of (a) melanin content and (b) the fibrocytes number in the skin around keloid and keloid region

than those without keloid (Figure 6). The highest ratio of melanin content in the surrounding skin and keloid tissue was $1: 3(42 \%)$ (Figure 7a). Meanwhile, the highest ratio of the number of fibrocytes in the surrounding skin and keloid tissue was 1:2 (62\%) (Figure 7b).

Table 3: The result of melanin content and number of fibrocytes number based on the keloid location and gender

\begin{tabular}{llllll}
\hline Gender & Melanin & & & Fibrocyte & \\
\cline { 2 - 3 } \cline { 5 - 6 } & Around keloid & Keloid & & Around keloid & Keloid \\
\hline General & 65.97 & 135.11 & & 510.86 & 176 \\
Men & 76.13 & 146.53 & & 506.67 & 159.33 \\
Women & 58.35 & 126.55 & & 514 & 188.5 \\
\hline
\end{tabular}

The correlation analysis showed a significant result between the melanin content and the number of fibrocytes in the surrounding skin and keloid tissue based on the Pearson correlation analysis. The melanin content in the surrounding skin had a smaller value $(-0.79)$ than the melanin content in the keloid tissue $(-0.89)$. These results had significantly different values $p=0.000$. Based on the partial correlation analysis, it showed a correlation between the melanin content in the surrounding skin as analysis variable and melanin content in keloid region as control had a higher result $(-0.09)$ than the correlation between melanin content in keloid as analysis variable and melanin content around keloid region as a control variable $(-0.68)$.

The relationship between the melanin content around the keloid with a density of collagen in keloid showed a reverse linear pattern. The number of fibrocytes in the keloid tissue decreases as the melanin content increases. The relationship between the melanin content and collagen density in the keloid also had the same result, which indicated an inversely linear 
pattern, such that the as the melanin content increases, the number of fibrocytes decreases.

Simple linear regression analysis results showed a significant effect of the variable content between melanin content around keloids and fibrocytes number in it (0.632) and they had a significant relationship (0.80). The results of the multiple linear regression analysis between the melanin content in the surrounding skin and the keloid tissue with the number of fibrocytes also showed that a negative value between melanin in keloid region and fibrocytes number $(-2.14)$. The same negative result was also obtained in melanin and fibrocytes number in the surrounding skin $(-0.17)$. This result indicated the melanin content in the surrounding skin and the keloid tissue decreases as the number of fibrocytes increases.

The average number of fibrocytes in the surrounding skin and the keloid tissue in women was higher than in men, which shows that the collagen density in women is lower than that of men. Furthermore, the melanin content and collagen density in women were poor. This result was supported by t-test that showed a significant difference between the melanin content in the surrounding skin and the keloid tissue, with a t-count value of $-10.66(p=0.00)$. The same was also observed for collagen density with a value of $21.46(p=0.000)$.

The correlation test showed a significant relationship between the melanin content in the surrounding skin and the number of fibrocytes with a correlation coefficient of $-0.795(p=0.00)$. The same was observed for these parameters in it with a correlation coefficient of -0.896 and $p=0.00$. This shows that the melanin content tends to increase and the number of fibrocytes was low in the surrounding skin and the keloid tissue. The analysis was sharpened using the first level of partial correlation analysis, which showed that between melanin content and the number of fibrocytes in the keloid tissue, the value is $-0.684(p=0.00)$. This was supported by a relationship pattern that showed a tendency for higher melanin content, followed by a low number of fibrocytes.

The linear regression test found a significant relationship between the melanin content in the surrounding skin and the number of fibrocytes with a determination coefficient of $0.63(p=0.00)$. The same was also observed for those with a coefficient determination of $0.80(p=0.00)$. The multiple linear regression analysis showed that the effect of melanin on keloid tissue had a greater role compared with those in the surrounding skin.

\section{Discussion}

Based on this study, the highest age range distribution in keloid patients was 10-30 years. It is important to point out that the age of subjects affects the frequency of keloid occurrence. This result was proportional with studies from Smith and McGrouther, who reported that keloids are often experienced by individuals within the age range of 10-30 years [17]. The same was found by Udo-Affah, who found the highest frequency in people who are 22-29 years old [18]. However, an increase in elastic skin conditions and high hormonal activity can also affect this condition (5). Based on UV exposure, it was discovered that with active and productive such that most of their activities are conducted outside, thus the risk of getting UV exposure was high, and consequently increasing keloid [19], [20].

Most keloid patients were women (65.4\%) and a lower percentage (34.6\%) of them were men. According to Udo-Affah, the number of women experiencing keloids is higher than in men [18]. Meanwhile, Shaheen et al. (2016) revealed that the incidence is the same in both sexes. Piercing marks were found to be the highest cause in women (30.8\%) [21]. Younger women prefer to add 1 or 2 holes in the ears, putting them at higher risk for keloids. Meanwhile, burns were discovered to be the highest cause in men $(30.8 \%)$. This is because they are breadwinners and actively work in environments that have a higher risk of trauma. Furthermore, the longest period for the disease was found to be 1-3 years, and some others were discovered to have it more than 3 years after the injury. It usually appears from months to years after trauma [5], [22]. Based on location, it is mostly found in the head and around the neck. Women had the highest number in this case because of their piercings. Previous studies also explained that the ear and neck areas are places where keloids mostly develop [23], [24].

Observation of keloid samples showed that it occurs mostly in areas that are exposed to UV light, as shown by $69 \%$, while the unexposed areas (covered by clothing) were $31 \%$. A high number of melanocytes are produced, which increases melanin synthesis due to exposure. However, melanin can block the destruction of collagen due to UV light [25], [26].

It was found that the predilection area (chest, deltoid, back, legs, and abdomen) had a higher $L^{*}$ value than around the keloid, but this value is smaller compared with what was got for the inner upper arm region. This indicates that the highest melanin content was found around the keloid region, with the lowest in the inner upper arm region.

The average $L^{*}$ value of women in each location was higher than in men. Previous studies have shown that women tend to have brighter skin than men do. The color brightness level will increase concomitantly with the enhancement of the $L^{*}$ value [27], [28], [29]. In addition, the value of skin exposed to UV light had a higher level of melanin than the unexposed area. Meanwhile, the enhancement of melanin occurred in the surrounding skin and the keloid tissue exposed to UV light. This result indicates that the amount of melanin increased because of the exposure [30].

The melanin content in histological preparations showed that the maximum combination 
score in the surrounding skin has similarity with the minimum combined score in it. The result revealed that the content in it is higher than the one around it. The average melanin content in women is lower than that of men because their skin is generally brighter [31]. Meanwhile, collagen density showed that the highest average combined score was found in 10-40 years old.

Collagen density was assessed by calculating the number of fibrocytes such that a small number indicates higher density and vice versa [32]. The results showed that the number of fibrocytes in the surrounding skin was 3 times higher than that in the keloid tissue. This shows that the collagen in the keloid tissue was solid. A previous study reported an increase in the thymic stromal lymphopoietin, which is a type of cytokine that increases collagen in keloid tissue [33].

\section{Conclusion}

This study displayed significant differences between the melanin content and the collagen density in keloid patients based on the results of $L^{*}$ objective values and histological observations. The melanin content increased as well as the collagen density decreased in keloid patient's tissue. Further research needs to be conducted to find the factors that cause collagen accumulation, the mechanisms associated with high melanin content so that it can be used to prevent and treat abnormal scars caused by high melanin pigment.

\section{Acknowledgments}

The authors would like to acknowledge Polyclinic of Plastic Surgery and Integrated Central Surgical Building (GBPT) Dr. Soetomo Hospital Surabaya and Brawijaya University for the support this research activity.

\section{References}

1. Mari W, Alsabri SG, Tabal N, Younes S, Sherif A, Simman R. Novel insights on understanding of keloid scar: Article review. J Am Coll Clin Wound Spec. 2016;7(1-3):1-7. https://doi. org/10.1016/j.jccw.2016.10.001 PMid:28053861

2. Shaheen A. Comprehensive review of keloid formation. Clin Res Dermatol. 2017;4(5):1-18.

3. Tiong WH, Basiron NH. Challenging diagnosis of a rare case of spontaneous keloid scar. J Med Cases. 2014;5(8):466-9. https:// doi.org/10.14740/jmc1887w

4. Glass DA. Current understanding of the genetic causes of keloid formation. J Investig Dermatol Symp Proc. 2017;18(2):S50-3. PMid:28941494

5. Shaheen AA. Risk factors of keloids: A mini review. Austin $J$ Derm. 2017;4(2):1074.

6. Andrews JP, Marttala J, Macarak E, Rosenbloom J, Uitto J. Keloids: The paradigm of skin fibrosis pathomechanisms and treatment. Matrix Biol. 2016;51:37-46. https://doi.org/10.1016/j. matbio.2016.01.013

PMid:26844756

7. Ramos MF, Attar M, Stern ME. Safety evaluation of ocular drugs. In: Faqi AS, editor. A Comprehensive Guide to Toxicology in Nonclinical Drug Development. $2^{\text {nd }}$ ed. Oxford, UK: Elsevier Inc.; 2017. p. 757-811. https://doi.org/10.1016/ b978-0-12-803620-4.00029-3

8. Treesirichod A, Chansakulporn S, Wattanapan P. Correlation between skin color evaluation by skin color scale chart and narrowband reflectance spectrophotometer. Indian J Dermatol. 2014;59(4):339-42. https://doi.org/10.4103/0019-5154.135476 PMid:25071249

9. Bryjova I, Kubicek J, Kasik V, Kamensky D, Klosova H, Penhaker M, et al. Objective Measurement of Hypertrophic Scars Using Skin Colorimeter. Proceedings of the $10^{\text {th }}$ International Joint Conference on Biomedical Engineering Systems and Technologies (BIOSTEC 2017); 2017 Feb 21-23. Porto, Portugal: Scitepress-Science and Technology Publications; 2017. p. 126-33. https://doi.org/10.5220/0006147101260133

10. Wang M, Luo MR, Xiao K, Wuerger S. The colour shifting of measuring human skin colour use different instruments. In: Ouyang $\mathrm{Y}, \mathrm{Xu} \mathrm{M}$, Yang L, Ouyang $\mathrm{Y}$, editors. Advanced Graphic Communications, Packaging Technology and Materials. Singapore: Springer; 2016. p. 9-15. https://doi. org/10.1007/978-981-10-0072-0_2

11. Kalleberg K, Nip J, Gossage K. Multispectral imaging as a too for melanin detection. J Histotechnol. 2015;38(1):14-21. https:// doi.org/10.1179/2046023614y.0000000054

12. Xue M, Jackson CJ. Extracellular matrix reorganization during wound healing and its impact on abnormal scarring. Adv Wound Care (New Rochelle). 2015;4(3):119-36. https://doi.org/10.1089/ wound.2013.0485 PMid:25785236

13. Wu S, Huang Y, Li Z, Wu H, Li H. Collagen features of dermatofibrosarcoma protuberans skin base on multiphoton microscopy. Technol Cancer Res Treat. 2018;17:1533033818796775. https://doi. org/10.1177/1533033818796775 PMid:30213241

14. Goyal S, Saini I, Goyal S. Familial keloid in Indian scenario: Case report and review of literature. Open Access Libr J. 2015;2:e1578. https://doi.org/10.4236/oalib.1101578

15. Ogawa R, Okai K, Tokumura F, Mori K, Ohmori Y, Huang C, et al. The relationship between skin stretching/contraction and pathologic scarring: The important role of mechanical forces in keloid generation. Wound Repair Regen. 2012;20(2):149-57. https://doi.org/10.1111/j.1524-475x.2012.00766.x

PMid:22332721

16. Pudjirahardjo WJ, Poernomo $\mathrm{H}$, Machfoed $\mathrm{MH}$. Metode Penelitian dan Statistik Terapan. [Research Methods and Applied Statistics]. Surabaya, Indonesia: Airlangga University Press; 1993.

17. Smith OJ, McGrouther DA. The natural history and spontaneous resolution of keloid scars. J Plast Reconstr Aesthet Surg. 2014;67(1):87-92. 


\section{PMid:24184068}

18. Udo-Affah GU, Eru EM, Idika CI, Njoku CC, Uruakpa KC. The age and sex incidence of keloids/hypertrophic scars in Calabar Metropolis, Cross River State from 2001-2006. J Biol Agric Healthc. 2014;4(11):33-7.

19. D'Orazio J, Jarrett S, Amaro-Ortiz A, Scott T. UV radiation and the skin. Int J Mol Sci. 2013;14(6):12222-48. https://doi. org/10.3390/ijms 140612222

PMid:23749111

20. Hochman B, Isoldi FC, Furtado F, Ferreira LM. New approach to the understanding of keloid: Psychoneuroimmune-endocrine aspects. Clin Cosmet Investig Dermatol. 2015;8:67-73. https:// doi.org/10.2147/ccid.s49195 PMid:25709489

21. Shaheen A, Khaddam J, Kesh F. Risk factors of keloids in Syrians. BMC Dermatol. 2016;16(1):13. https://doi.org/10.1186/ s12895-016-0050-5

PMid:27646558

22. Schneider M, Meites E, Daane, SP. Keloids: Which treatment is best for your patient? J Fam Pract. 2013;62(5):227-33. PMid:23691533

23. Di Stadio A. Ear keloid treated with infiltrated non-cross-linked hyaluronic acid and cortisone therapy. In Vivo. 2016;30(5):695-9. PMid:27566093

24. Walliczek U, Engel S, Weiss C, Aderhold C, Lippert C, Wenzel A, et al. Clinical outcome and quality of life after a multimodal therapy approach to ear keloids. JAMA Facial Plast Surg. 2015;17(5):333-9. https://doi.org/10.1001/jamafacial.2015.0881 PMid:26270082

25. Chiarelli-Neto O, Ferreira AS, Martins WK, Pavani C, Severino D, Faião-Flores $\mathrm{F}$, et al. Melanin photosensitization and the effect of visible light on epithelial cells. PLoS One. 2014;9(11):e113266. https://doi.org/10.1371/journal.pone.0113266 PMid:25405352

26. Kim E, Kim D, Yoo S, Hong YH, Han SY, Jeong S, et al. The skin protective effects of compound $\mathrm{K}$, a metabolite of ginsenoside
Rb1 from Panax ginseng. J Ginseng Res. 2018;42(2):218-24. https://doi.org/10.1016/j.jgr.2017.03.007

PMid:29719469

27. Hourblin V, Nouveau S, Roy N, de Lacharriere O. Skin complexion and pigmentary disorders in facial skin of 1204 women in 4 Indian cities. Indian J Dermatol Venereol Leprol. 2014;80(5):395-401. https://doi.org/10.4103/0378-6323.140290 PMid:25201838

28. Huang WS, Wang YW, Hung KC, Hsieh PS, Fu KY, Dai LG, et al. High correlation between skin color based on CIELAB color space, epidermal melanocyte ratio, and melanocyte melanin content. PeerJ. 2018;6:e4815. https://doi.org/10.7717/peerj.4815 PMid:29844968

29. Jones AL, Russell R, Ward R. Cosmetics alter biologically-based factors of beauty: Evidence from facial contrast. Evol Psychol. 2015;13(1):210-29. https://doi. org/10.1177/147470491501300113 PMid:25725411

30. Sarkar R, Bansal S. Skin pigmentation in relation to gender: Truth and myth. Pigment Int. 2017;4(1):1-2. https://doi. org/10.4103/2349-5847.208350

31. Amaro-Ortiz A, Yan B, D'Orazio JA. Ultraviolet radiation, aging and the skin: Prevention of damage by topical cAMP manipulation. Molecules. 2014;19(5):6202-19. https://doi. org/10.3390/molecules 19056202

PMid:24838074

32. Sibilla S, Godfrey M, Brewer S, Budh-Raja A, Genovese L. An overview of the beneficial effects of hydrolysed collagen as a nutraceutical on skin properties: Scientific background and clinical studies. Open Nutraceuticals J. 2015;8:29-42. https:// doi.org/10.2174/1876396001508010029

33. Shin JU, Kim SH, Kim H, Noh JY, Jin S, Park CO, et al. TSLP is a potential initiator of collagen synthesis and an activator of CXCR4/SDF-1 axis in keloid pathogenesis. J Invest Dermatol. 2016;136(2):507-15. https://doi.org/10.1016/j.jid.2015.11.008 PMid:26824743 